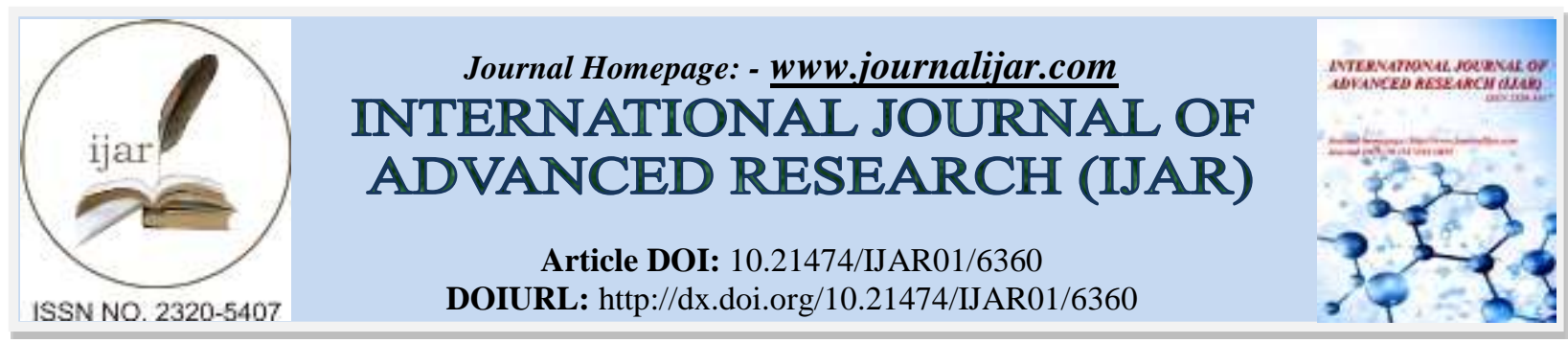

RESEARCH ARTICLE

\title{
MORAL AS A CRITICAL TEST IN ESTABLISHMENT OF THE LAW.
}

Senior Lecturer, Faculty Of Law Pattimura University, Ambon, Maluku Province
Manuscript Info

Copy Right, IJAR, 2018,. All rights reserved.

\begin{abstract}
Introduction:-
Indonesia is a state based on law (rechtsstaat), not based on mere power (maachtsstaat). Subsequently in Article 1 paragraph (3) of the 1945 Constitution of the Republic of Indonesia states that "the State of Indonesia is a State of law". The state law according to Satjipto Rahardjo is synonymous with the building of laws and regulations. Its quality is only determined by its submission to the law. Such a type is commonly referred to as a formal State of law which has no specific humanitarian standard or character as a determinant. The ruler becomes free to determine and follow the politics he makes himself. The only determinant is the wisdom it makes in the law.
\end{abstract}

The law built in the building of legislation has the purpose of straying relationships in a society where the hope of justice and prosperity can be achieved. This goal can be achieved through a long process involving various groups, both government and legislators. The laws governing the life of the people within the State of Indonesia also go through the process until it is acceptable to the public. The resulting law is expected to fulfill a sense of justice for the people who will implement it in a collective life

\section{Moral as a Critical Test in the Formation of the Act:-}

In all aspects of human life, morals have functions and roles that are very important and decisive. This means that life is not based on morality so the whole community order becomes chaotic and meaningless. By morals, that right will require everyone to act and behave in a good and right way, and meaningful to others.

Moral actually has a close relationship with the norm, because in the presence of norms that contain good values then it will be the correct foundation in demanding the whole association of human life. 
Moral refers more to the good of humanity, guiding humans how they should live or what they should and what not to do. In social life, all societies have moral rules that allow or forbid certain acts. The conduct must be followed by members of the community and will incur punishment for the offender. Moral measure should be based on cultural values that arise and develop within the community and / or religion adopted. ${ }^{1}$

Moral is actually related to ethics, because according to Frans Magnis Susesno, professional ethics is a process of having principles that must be upheld. Those principles are set forth in the code of ethics of the profession. ${ }^{2}$ The Legislator is also a profession that must respect value, ethics and morals, so that its products are meaningful to the life of society, nation and state.

The law is a written part of the law, which in the process of its formation must be based on a critical test stone that is the moral itself. Moral will be a critical test stone, it means that morality is always used as the basis of thinking in thinking and acting and not deviating from intellectual reasoning ability.

Associated with the foregoing according to Bernard Arief Sidharta, legal discourse refers to the intellectual process to: (a) directly influence thoughts and actions; (b) preservation and development of traditions and legal values living in a politically organized legal society as a whole; (c) preservation and development of traditions and values of the legal profession ${ }^{3}$.

It is further asserted that one form of discourse is legal rhetoric. In a general sense, rhetoric refers to the art of persuasion through "appeals to emotions" and the art of general support through "appeals to reason" as a way of reasoning. Rhetoric uses subjunctive, normative and imperative statements, which are put forward to influence people's thoughts or behaviors. The rule of law that is usually formulated in an indicative sentence actually has a rhetorical significance in addition to logical significance. The rhetorical aspect of legal reasoning is directed at behavior, on legal activity that includes both the formation of law and the granting of legal judgments. Thus, the rhetoric of law is aimed at influencing thought and behavior in the formation of law and decision-making law. The hallmark of the rhetoric of the law is "appeal to authority" (referring to authority, authority, legal basis) that refers to what is commonly called the legal source (formal) that grants the authority. The sources of law that are now known and generally recognized are legislation (including treaties), precedents (jurisprudence), habits, and equities rooted in legal awareness or sense of justice. In the rhetoric of the law, the reason for which to base an opinion ultimately will always refer to the source device of the law ${ }^{4}$.

Based on the above view it turns out intellectuals are always associated with the ability to think rationally where reason and morals must have a relationship that can support the structure of a rational beropikir also.

Intellectuals are not rational but must be followed by mental and moral morals that can really affect the whole structure of thinking and action. Without morality what is done only by reason or ratio that often can also deviate from the principles of dignified life. This means that when a person thinks and is followed by various actions then morals must be a critical test stone to sharpen the mind and conscience so as not to carry over the emotions and certain interests that ultimately lead to various problems in public life.

\section{Moral as Philosophical Foundation in shaping Laws:-}

Talking about the establishment of the Act then it is a difficult job. Distroy the rules means that no moral ${ }^{5}$. According to former Justice Minister Ali Said the job of forming the Act is a very difficult job because it is related to the human and human aspects.

Based on the above view it can be said that the work of forming this Law requires study of various fields and is based on the foundation or principles of the formulation of applicable legislation. Rugebregt said "Pancasila is no

\footnotetext{
${ }_{1}^{1}$ Marzuki Ali, Pemahaman Etika dan Moral Bangsa, hhtp//marzukialie Pebruari 2012

2 Yan Aipul, Etika Profesi Hukum, dalam Literatur www.ubb Pebruari 2012

${ }^{3}$ Bernard Arief Sidharta,2000, Refleksi tentang Struktur Ilmu Hukum, Mandar Maju, Bandung, p.165

${ }^{4}$ Ibid

${ }^{5}$ Mohammad Arief Amrullah, Revency Vania Rugebregt, Pattimura Law Journal, Volume 1 Ussue 2, March 2017, Copyright 2017 PALAU, Faculty of Law Pattimura University, Ambon, Maluku Indonesia, http://fhukum.unpatti.ac.id/jurnal/index.php?journal=palau.
} 
longer rooted in the heart and the tendency of other ideological practices is increasingly widespread without tolerance so that the dispute occurs because of the lack of alertness and the lack of government willingness in the face of turmoil. As a result law in this country is undergoing a process of decay. Moral law enforcers in doubt, even the morale of political elites was in question". " "Pancasila sudah tidak lagi mengakar dalam sanubari dan kecendrungan praktek ideologi lain semakin marak tanpa toleransi sehingga pertikaian terjadi karena ketidak sigapan dan ketidak siapan pemerintah dalam menghadapi gejolak. Alhasil hukum di negara ini memang sedang mengalami proses pembusukan. Moral para penegak hukum di ragukan, bahkan moral para elite politiknya pun di pertanyakan")

Here one of the most important aspects is the philosophical aspect, ie deep studies of the nature, process or deepening and value or benefit for the benefit of society, nation and state.

The philosophical aspect is directed to deep insights about the human and human aspects. Here actually the value and morals is one of the very important and decisive, because the forming of the Act is a man who is influenced by various things both internal and external.

Men are regarded as the driving force in making a significant contribution to the establishment of a Law. The law is seen as a crystallization of the values that live and thrive in society. Moral thus plays a very important and decisive role. This means that the Law which is the soul of the society must be formed based on objective thoughts and will provide great benefits for the community as the user of the Act.

In the formulation of the Act it can not be denied that interest is always an important factor that deserves a deep study. It is said that because the interest always tempts everyone, especially the legislators to formulate the legal norms in favor of power and certain parties in the dynamics of the life of the nation and state.

Related to the interest, according to Pound theory of interest, it is said that interest is the core of the science of law. Pound says that interest is a desire or demand that man wants to fulfill, either personally, through interpersonal or group relationships. He distinguished between personal interests, public interests and social interests. Among the social interest groups are, among others, the interests of public security, private life, protection of morals, conservation of social and natural resources, and interests in economic, political and cultural development. ${ }^{7}$ If associated with morals then it is related to the aspect of justice because morals always strive to create justice in society. Justice must have a tremendous influence on the development and development of the law especially in the formation of the Act.

So according to Pound, justice without law is carried out in accordance with the wishes or intuitions of a person who in making decisions has a wide scope of discretion and no attachment to a particular set of rules. The first form of justice is judicial, while the second has administrative features. Pound suggests that both forms of justice exist in all legal systems.

Pound argues that in the history of law there appears to be a movement between extensive discretion and firm and detailed rules. The pound questioned the problem in the future is to achieve a harmonious state between the elements of judus and the administrative as well as with justice. Pound's view on pataut accepted because harmonization is an interesting and important thing in organizing the whole structure of thinking and acting, so it is not affected on the various interests that ultimately gave birth to the formulation of norms that are not based apada philosophical aspects.

Philosophical views are important and decisive not only in the consideration of a rule of law or the Law, but they must be reflected in harmony throughout the structure and substance of the Law. This means that all aspects of human needs and interests that want to be regulated in a Law should be arranged in harmony and have a solid footing and true based on academic and social values are adequate.

6 Revency Vania Rugebregt, Perenungan Tentang Keterpurukan Hukum di Negeri Ini, http://fhukum.unpatti.ac.id/htn-han/161-perenungan-tentang-keterpurukan-hukum-di-negeri-ini, diakses januari 2017

${ }^{7}$ Roscoe Pound dalam Soejono Soekanto : 1985, Penelitian Hukum Normativ, Suatu Tinjauan Singkat, Rajawali Pers, Jakarta, p.32 
The value of academic value does not always appear in the life of the campus but it can appear in everyday life in a constantly changing society. In political life and moral law has a function and role that is very important and decisive. Moral politics is reflected in the behavior of cadres and legislative members. It also appears in various products of legislation.

The formation of a law or Act as part of political activity must also be based on the morals of its investors. Therefore, the moral lawmakers will produce spectacular works in the field of law containing moral values as well.

\section{The Factors Affecting Moral in Formation the Act:-}

Legislation in any State is always made man with a mindset in his mind. This fundamental thinking can be influenced by factors such as ideological or religious beliefs, experiences, knowledge and also interests. These interests can also vary such as personal interests, interests of groups or parties, interests of the people or foreign interests.

Of all the above factors, The most dangerous is when foreign interests dominate. Although the interests of the common people may be wrong or contradict certain beliefs (ideologies and religions), at least the real effects will be felt in the long run. But if the dominant foreign interest is predictable, that within a short period of legislation it will already cause widespread disaster for the community.

Therefore, it is important to be aware of foreign intervention in lawmaking in Indonesia and it is not always easy to obtain evidence of foreign intervention in the legislation process. Foreign interventions that can be mentioned in this thesis are the results of an analysis of a number of phenomena and information obtained.

In general these interventions can be categorized into five group methods, namely:

First, government to government intervention, that is, foreign governments directly pressure the government of a country to include a clause or agenda in its legislation. This model does look rough (vulgar), so easy to criticize, but the fact often happens. for example a statement that Indonesia's terrorist nest, whether exposed by the United States, Australia or Singapore, aims to urge Indonesia to adopt more stringent anti-terrorist laws.

Second, the intervention of international institutions such as the UN, WTO, IMF that take the role of suppressors. This group is a bit more "elegant" because it seems as if the agenda to be imposed is international agreements. It is as if the recommendation of the international institution as an ideal because it meets the "standard and international norms". If not followed can be isolated or no longer appropriate to receive "world cooperation" (receiving debt or assistance).

Third, the intervention of the business world, whether the business has an international network or business that only moves in the domain of domistik. These entrepreneurs and investors can pressure governments to smooth their interests in legislation. Not infrequently, foreign entrepreneurs use their local partners to speak more loudly, so as not to be impressed there is a foreign interest behind it. The threat that often arises is to move investments into other "better tempered" countries. For example, the agenda of laws related to investment, taxation and hunting.

Fourth, the intervention of non-governmental organizations (non-government organizations). NGOs including mass organizations can be effective pressure groups on government, legislative bodies and judiciary bodies. By way of coming to the drafters of the law as a form of mental terror until large-scale demonstrations are quite troublesome government if the government does not obey their wishes. For example; controversy of anti Pornography and Porno action Act.

Fifthly, the intervention of intellectuals (intellectual to government), scientists, consultant institutions, and even religious leaders can be used to pressure the government to pass an agenda in its legislation. Bureaucrats and drafters of the law are also sometimes invited by parties abroad to comparative studies and meet with experts abroad. In education or scientific meetings that can occur very subtle intervention. In reality, this pattern of intellectuals is the kindest and most difficult of the interventions to detect, because what will emerge is the beliefs of the nation's own children. But this intellectual pattern is only used for long-term intervention, because "the process of forming an intellectual agent" takes time. 
This condition is quite apprehensive because in the formation of the Act was not free from the intrigues of political intrigue that affect the entire process.

It is realized that the law can not be separated from the political influence but the law or established Law must contain high values and morals so that really useful for the benefit of society. Without ethics and morals, the law will become a political instrument or a ruler who only accommodates certain interests. If it goes on then it is difficult to get justice in society.

Society will only be the disadvantaged party with the less moral moral product. In the case of the people entrusting all their rights through their representatives sitting in legislative institutions to fight for the interests of the people or society.

Legislators in many ways forget, that he bears or assumes the noble duties and responsibilities entrusted by his constituents. If the responsibility is not carried out properly then the victims are the people or the community itself. When entering the legislative body legislative members are given the main task of trying to maximize the interests of the people, the moral representatives of the people must realize and understand that people's trust is noble and should not be wasted away.

The people as the holder of power must be the main priority not the other political interests. Conditions that occur today people are sacrificed for the sake of politics. Members of the legislature betray his promises and move to fight for the interests of others who have money and power.

Indonesia's political world becomes blurred and difficult to be dammed only by using the rule of law alone, but must be followed by philosophical and moral principles of thought, so that legislative products are truly weighted and serve the interests of the people.

The law is often referred to as a political product because it is formed on a political institution. This is true but it can not be allowed to be mocked by politics. The presence of the law is noble because it accommodates all the aspirations and values of living in society, so that people can live safely, peacefully, prosperously and justly and ensure legal certainty for all levels of society.

\section{Political Influence on the power of the Law: -}

H. Hufron said that law and politics is a sub system in the social system. Each performs a certain function to mobilize the entire social system. In essence, the law functions to do social control, dispute settlement and social engineering or innovation, while political functions include system maintenance and adulation (socialization and recruitment), conversion (rule making, rule aplication, rule adjudication, interest articulation and aggregation) and capability functions (regulative, extractif, distributive and responsive).

Although law and politics have different functions and justification, but in terms of the objectives thereof, complement each other and support the realization of the state's goal of social justice. Each must contribute in accordance with its function to mobilize the social system as a whole, especially in the commitment to support the implementation of development. The responsible government means being able to realize the real functioning of the public economy that is the allocation, distribution and stabilization function of resources owned by the state.

Muladi, further concluded that an ethical leader must be free of unethical, corrupt behavior, and should take over greater responsibilities. The applicable ethical standards of profession should contain the following characteristics: (a) Responsibility and accountability, which contain the ability to recognize strengths and weaknesses; (b) Commitment, dedicated to the role of the organization and full of commitment to the laws, codes, regulations and standards of professional conduct; (c) Responsiveness, sensitivity and flexibility to changing situations and the needs and demands of the community; (d) Knowledge and skills, capable of completing the mission of the organization on the basis of scientific and technological developments that are particularly relevant in interpreting relevant data; (e) Conflict of interest, sensitive to the ever-present conflict of interests between individual needs and organizational needs; and (f) Professional ethics, should always do self-reflection and check if its decision is against ethical standards. ${ }^{8}$

\footnotetext{
${ }^{8}$ Muladi, dalam Hufron, 2003, Aspek Moral dan Etika Dalam Penegakan Hukum Pidana, p.19-20
} 
Legal development management is a subsystem of national development management. In accordance with the nature of management, the development of managed law also recognizes the dimensions of planning (planning), organizing all potential and existing capital, financing (budgeting), coordination, supervision, and other dimensions are commonly known in management theory.

In accordance with the nature of the strategy, the management of the national law will be strategic, if it is done by recruiting and directing all existing potentials and involving them in the series of development and legal development activities, to achieve the objectives that have been politically formulated in Haluan Country (formerly GBHN, now RPJPN = National Long Term Development Plan).

The development of national law is more oriented towards quantity than quality. That is what is being pursued is the quantity not the quality of a Law. A problem that must be governed by only one Law, is in fact broken into several laws with the sole purpose of obtaining the material rather than regulating the substance in depth based on the needs and interests of the community. Such a condition is very apprehensive and it is actually related to the moral of the legislators who are less concerned about the crucial issues that must be regulated well, but directing attention only on things that are superficial and less lead to aspects of life aspects together as the nation the plural.

Moral issues that form the basis of the formation of a law cover a broad aspect not only related to the formulation of norms, but it actually originated from the initial intentions and thoughts about the plan of its formation.

Prosperity and prosperity are actually the main targets, not the political and economic interests of a group of people who are always interfering with individuals, groups, political parties, religious organizations, civic organizations, certain economic or trade associations and others who always want to feel secure and take refuge behind the political product.

The question that needs to be answered with regard to this sub-section is what is the contribution of our legislative instrument to the engineering of prosperous, just and prosperous society. The question becomes relevant when we look at / examine the law and the legislation as etalasi and not as a norm that is empty room. However, looking at the law as an ever-present and intuitive amid the dynamics of people's lives while remaining within a scope of legal development problems. People's welfare is the goal of national policy, which is inseparable from legal and political relations.

There are four political influences on the strength of law that is as follows:

First, it is clear that politics has an impact on the law. These two aspects of life (politics and law) are evident from the fact that law is the product of the political process without the need to distinguish whether the process takes on political actors who have equal powers or are exercised through the domination of a party. In addition, the political relationship with the law is also demonstrated by the process of establishing legal institutions, the establishment of legal personnel, and the legal process itself, at least, according to circumstances, politics has the potential to influence the law in every point of law life.

Secondly, at every political meeting point with the law there are two possible political impacts on the law, namely the opportunity for legal growth or negatively affecting both inhibiting its growth and weakening its power.

Third, the journey of political life of the Indonesian nation is marked by an increase in the gap in the role of political elite (ruler) with the society and the middle class even though everything goes increasingly unidirectional. The phenomenon is indicated by the accelerated development of political mobilization rather than the growth of political participation. At the same time there are also legal developments that indicate a gap between the growth of the structure and its function. This means that in the course of legal life the legal structure shows relatively rapid progress while its functions are left behind.

Fourthly, the positive or not of political influence over the law is determined by the combination between the political actors, their patterns of political behavior and the element of the law itself. The possibilities are as follows:

1. Both in political life characterized by mobilization and colored by a combination of mobilization with participation, the legal structure has the opportunity to develop. Consider the growth of the physical nature of the 
law (the product of legislation), legal institutions and legal personnel that occur, in the reform era even though political life has its ups and downs;

2. Political mobilization is the main characteristic of political behavior, it seems that the function of law in the sense that the authority of judges, police, prosecutors and legal and material substances does not show adequate growth. The reason, lies in the absence or ineffectiveness of social political mechanisms for ethical (moral) attribution to politics. Equality of political resources and socio-economic equalization;

3. The political behavior of society which is more manifested in the form of participation rather than mobilization, has a big chance as a driver of the development of legal functions.

4. There is an indication that any political behavior is beneficial to the development of the legal structure, in addition to the sign that participation as a form of political behavior encourages its growth of legal function, it is reasonable to say that in the belief in political stability as a choice among the mobilization participation has not been shaken, a safe way to develop a political contribution to legal growth is to build a balance of political behavior through mobilization with participation.

From the picture above shows that the relationship between politics and law goes in two directions, so that both aspects of the law of life as an indicator of the growth of people's welfare, in order to trace the facts that allow the growth of political power is seen as a variable that affects the positive law.

The focus of attention is the development of law amidst societies that are influenced by politics. Legal development here is distinguished on three aspects of its structure, namely First, physical form, the scope of its validity, Secondly, its implementation bodies, personnel and legal positions and aspects of its function. Third, the authority of law officials and legal substance.

There is a meeting point between politics and law in the life of the community, namely:

First, at the time of judicial appointment, although not all law-enforcement processes involved politics, but the process was open to political engagement;

Secondly, the process of making the law itself, any formal policy-making process which results in the law is essentially a product of political outcomes;

Third, the process of enforcement of the law, in which the parties concerned attempt to influence the implementation of policies already in the form of law, in line with the interests and strength.

Legal political relations in Indonesia include:

Political rights and their manifestations;

That civil rights and politics are defined as rights acquired by citizens because they are prescribed in laws such as the constitution and laws. Therefore these rights are commonly fought through the courts. In contrast to political rights, civil rights are granted to every citizen. In a democratic country civil rights include: personal habits; protection of property rights; protection from arbitrary detention and imprisonment; the right to proceed in the judicial process to defend the interests of the government bureaucracy. Political rights are granted to all citizens. There are several requirements to be able to enjoy political rights, such as: age, place of residence, free from criminal action and so forth.

Therefore, political rights are often said to be not rights in the real sense. Political rights are created by law and given to anyone who meets certain requirements, not to every resident. Into the political right is the right to vote, the right to participate in the political process and the right to occupy a certain position within the State.

In the 1945 Constitution there is a distinction between political rights and civil rights not expressly stated, after the amendment of the 1945 Constitution of the Republic of Indonesia of 1945 political rights and civil rights have been regulated explicitly and universally.

Based on the above mentioned constitutional political changes, the pattern and behavior of the society, the government, and the political elites should make the constitution (the 1945 Constitution of the Republic of Indonesia Year 1945) a foundation and act to uphold the constitutional rights of citizens guaranteed in the constitution. 
The political behavior of the elite (ruler) and the public as the realization of political rights;

The use of political rights in Indonesia is divided into two groups, namely:

First, political rights reflected by the political behavior of the masses are the use of voting rights in elections, the involvement of the masses in political organizations and the participation of the masses in political movements such as demonstrations. All of this is defined as political participation on the one hand and political mobilization on the other.

Second, the political rights reflected in the political behavior of the authorities can be understood by: the procedure of treating power such as concentration of power as well as intervention in lawmaking. Procedures for the use of forms of power relations between the ruling elite and between the ruling elite with community.

Therefore the realization of political rights as a factor encompassing the process or the life of the law of the people, is a legal resource that enables the law to develop in its entirety.

The development of the relationship of political behavior with the law;

The development of legal politics with the development of law in the institutional aspects is observed through the forms (nature) and the legal legality that are differentiated on (1) formal aspects and material aspects; (2) the basis of its use consists of force and legitimacy, (3) its benefits to society, namely order and justice.

These three indicators of legal development can be substantially combined with the conditions of the process of forming the law and the legal process itself. Nevertheless, there is a tendency for more combinations to be determined by the emphasis of legal objectives in the form of benefits to the lives of people affected by the process of political behavior such as the process of establishing a legal product often running for a long time (difficulty) as well as the design and process of approval and approval in the DPR .

the cultural factor of the structure as the background of the pattern of elitist and societal behavioral relations with the development of law.

Culturally, political participation as a legal resource is determined by the relationship between ethics, morals and norms with political behavior on the one hand and the mastery of political order or procedure also called political techonology on the other.

In addition, there are also procedures or procedures that are not formal or only agreed on a continuous basis, so it has become a tradition, culture and may also have been accepted as a convention.

\section{Closing:-}

Power and knowledge lead to the growth of elite political behavior (rulers) which further encourage the development of a "short cut" political process whereby the outcome or objectives are preferred to weigh the process itself. Weak community power does not help elite kekkuasaan to trace the procedure. Consequently the law as a rule of procedure lacks the power to develop. Because in the process of law-making and so are its uses, where society has no powerful path and activities to put its interests into consideration, their contribution to the field of law has not yet developed. It lacks responsibility for the product and legal process, so that the public lacks trust and then does not endeavor to support it.

\section{Reference:-}

1. Satjipto Rahardjo,2009, Hukum dan Perubahan Sosial Suatu Tinjauan Teoritis Serta PengalamanPengalaman di Indonesia, Genta Publishing, Yogyakarta

2. Marzuki Ali, Pemahaman Etika dan Moral Bangsa, hhtp//marzukialie Pebruari 2012

3. Yan Aipul, Etika Profesi Hukum, dalam Literatur www.ubb Pebruari 2012

4. Bernard Arief Sidharta,2000, Refleksi tentang Struktur Ilmu Hukum, Mandar Maju, Bandung

5. Mohammad Arief Amrullah, Revency Vania Rugebregt, Pattimura Law Journal, Volume 1 Ussue 2, March 2017, Copyright 2017 PALAU, Faculty of Law Pattimura University, Ambon, Maluku Indonesia, http://fhukum.unpatti.ac.id/jurnal/index.php?journal=palau 
6. Revency Vania Rugebregt, Perenungan Tentang Keterpurukan Hukum di Negeri Ini, http://fhukum.unpatti.ac.id/htn-han/161-perenungan-tentang-keterpurukan-hukum-di-negeri-ini, diakses januari 2017

7. Roscoe Pound dalam Soejono Soekanto : 1985, Penelitian Hukum Normativ, Suatu Tinjauan Singkat, Rajawali Pers, Jakarta. 